\title{
Engineering geological mapping for empirical design evaluation of Tunnel 10 of Jakarta - Bandung high-speed railway, Indonesia
}

\author{
Hanifah Hilda Herdiana ${ }^{1,2}$, I Gde Budi Indrawan ${ }^{1 *}$, and Hendy Setiawan ${ }^{1}$ \\ ${ }^{1}$ Department of Geological Engineering, Faculty of Engineering, Universitas Gadjah Mada, Yogyakarta, Indonesia \\ ${ }^{2}$ Ministry of Public Works and Housing of Republic of Indonesia, Jakarta, Indonesia
}

\begin{abstract}
An engineering geological mapping was carried out at the construction site of the Tunnel 10 of Jakarta - Bandung High-Speed Railway to obtain data and information of the engineering geological conditions, particularly the rock masses. This research aims to determine the rock mass classes at the tunnel construction site and recommend the tunnel support system based on the Rock Mass Rating (RMR) and the Japan Society of Civil Engineers (JSCE) systems. This research is expected to better understand the rock mass classes, which were previously determined based on the newly applied Basic Quality (BQ) system for the tunnel support empirical design. The results showed that the research area consisted of young volcanic products, namely moderate to highly weathered tuff breccia and andesitic breccia. The uniaxial Compressive Strength (UCS) of rock mass varies between 1-25 MPa. The RMR value ranges from 21 to 40, indicating disintegrated and poor rock mass quality. The proposed tunnel support system is the combination of shotcrete, steel support for top heading and bench support, arch sidewall, and invert concrete.
\end{abstract}

\section{Introduction}

The Tunnel 10 of Jakarta - Bandung High-Speed Railway with 1230 meters of length and a maximum buried depth of 37 meters is located in Ngamprah District, West Bandung Regency, West Java Province of Indonesia. The tunnel is in the construction process and has three construction accesses from the entrance at DK $107+070$, the center of the tunnel (inclined shaft) at DK $107+685$, and the tunnel exit at DK $108+300$. Tunnel excavation is carried out using the New Austrian Tunneling Method (NATM) with the three-bench excavation method and temporary transverse reinforcement during excavation [1].

According to the Map of Earthquake Hazard of Indonesia and Digital Elevation Model (DEM) generated from satellite imagery, Tunnel 10 is located between 2 (two) active structures, namely the Cimandiri fault and the Lembang fault, as well as the hilly topography. Cimandiri fault is left-lateral reverse fault with $0.4-1.0 \mathrm{~mm} /$ year geodetic slip rate $[2,3]$ which located 2 kilometers southwest from the study area. Lembang fault is a strike-slip fault with dominant sinistral motion with an inferred fault within the study area. The slip rate of Lembang fault is $1.95-3.45 \mathrm{~mm} /$ year [4]. The two active faults in the study area with different movements can form joints in the rock mass. The presence of joints in the rock mass affects the rock mass quality, which is one of the tunnel design parameters.

The Geologic Map of the Cianjur Quadrangle of Java [5] shows that the study area resulted from young volcanoes in the form of tuffs originating from Mount Tangkuban Prahu (Qyt). Engineering geological mapping shows that rock mass in the study area mostly in highly weathered condition. Based on the bore log data, the groundwater table along the tunnel route is relatively high. Therefore, the strength of the layers along the tunnel route and its vicinity are non-uniform.

According to the conditions above, it is crucial to evaluate the geological conditions to determine the rock mass quality and characterization and feasible tunnel support system design for Tunnel 10 by means of engineering geological mapping and bore log data. This study aims to present rock mass quality and characterization and propose a tunnel support system that fits the geological condition and complexity in the study area.

Rock mass quality and characterization in this study were determined with the RMR method while the tunnel support system was referred to the RMR method and the JSCE method. Rock mass quality calculation and tunnel support system determination used in this study have never been used in this study area and the Tunnel 10 construction project. The previous method used to empirically determine the Tunnel 10 support system is rock mass classification according to Basic Quality (BQ) system.

\footnotetext{
* Corresponding author: igbindrawan@ugm.ac.id
} 


\subsection{Study area}

The study area is located about $31 \mathrm{~km}$ to the northwest of Bandung city (Fig. 1). Engineering geological mapping and surface rock sampling were carried out in the area of 1330 meters $x 955$ meters.

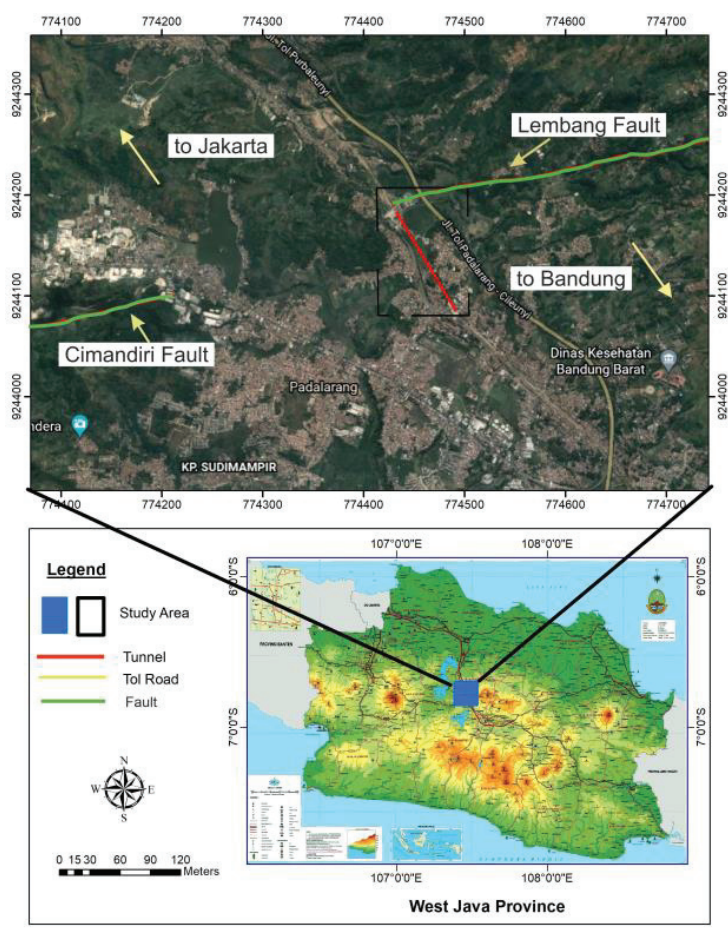

Fig. 1. Location of study area at Ngamprah District, West Bandung Regency, West Java Province of Indonesia [6].

\section{Regional geology}

\subsection{Topography}

The study area is covered by low hills with an undulating landscape (Fig. 2). Figure 2 shows that the lighter parts are hilly area and the darker parts are valley area. The tunnel route is located under rice fields, plantations, and settlements. According to the Design Drawing of No. 10 Tunnel (2018) of PT KCIC [1], the highest ground-level elevation in the tunnel alignment is $744 \mathrm{~m}$, and the lowest is $684 \mathrm{~m}$, with the slopes at the entrance and exit of the tunnel are $8^{\circ}-25^{\circ}$ and $3^{\circ}-13^{\circ}$, respectively.

\subsection{Lithology}

Tunnel 10 is located in the Quaternary Pleistocene volcanic sediment layer (Qyt), consisting of clay, silt, silty soil, fine sand, medium sand, coarse sand, grit, fine angular gravel soil, coarse angular gravel soil, and black stone soil [12]. Engineering geological mapping shows that study area consists of two main lithology units namely the andesitic breccia and tuff breccia. The andesitic breccia composed of andesite fragment from breccia with silt to sand as its matrix, while the tuff breccia consist of tuff as a fragment with silt to sand as its matrix. In addition, the andesitic breccia and tuff breccia are distributed on the surface with moderate to highly weathering conditions.

\subsection{Geological structures}

Tunnel 10 is located between the main geological structures, namely the Cimandiri fault and the Lembang fault. The Map of Earthquake Hazard of Indonesia (2017) show that the Cimandiri Fault has an estimated slip rate geodetic ranging from $0.4-1 \mathrm{~mm} /$ year [3], and the Lembang fault has an estimated slip rate of $3-14$ $\mathrm{mm} /$ year. The active segment of the Cimandiri fault is a dominant upward sinistral fault with a west-east and northeast-southwest orientations [7]. The location of the Cimandiri fault is in the southwest of the study area. The Lembang fault is a sinistral shear fault that cuts the Jakarta - Bandung High-Speed Railway line at DK $107+035$ [4].

The alignment of the valleys in the study area shows the direction of northeast - southwest. The direction indicates that the structure pattern in the study area is influenced by the regional fault called the Maratus Pattern. The faults on the Java Island are caused by the collision of the Eurasian plate with the IndianAustralian plate. The collision resulted in the formation of fault patterns in Java, including the Maratus Pattern that is represented by the Cimandiri fault [8].

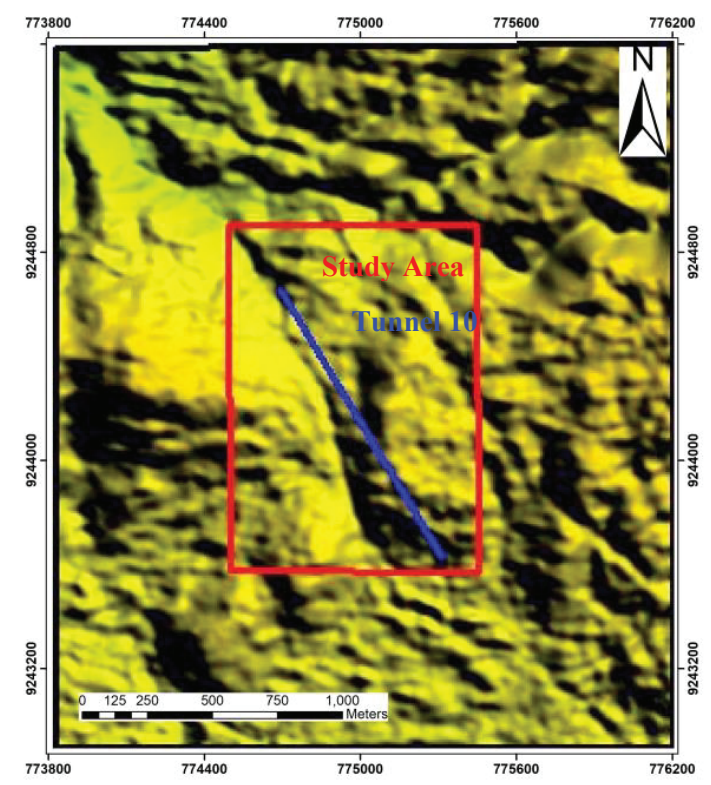

Fig. 2. Digital imagery of the study area and its vicinity.

\section{Methodology}

\subsection{Engineering geological mapping}

Engineering geological mapping was carried out to determine the morphological conditions, lithological distribution, and geological structure of the study area using a map scale of 1:5000. Surface rock samples were 
collected at various lithology and degree of weathering of rock mass. Combined with the bore $\log$ data, engineering geological mapping result was used to determine rock mass quality and to propose the tunnel support system based on morphological conditions, lithological distribution, and geological structure of the study area.

\subsection{Rock mass classification and determination of tunnel support system using the RMR method}

Classification of rock mass quality using the Rock Mass Rating (RMR) [9] method was carried out by determining the values of (1) strength of intact rock material, (2) the value of Rock Quality Designation (RQD), (3) spacing of discontinuities, (4) condition of discontinuities, (5) groundwater, and (6) discontinuity orientation. The strength of intact rock material in this study was determined by uniaxial compressive strength (UCS). The estimated field rock UCS values used in the RMR method obtained based on the ISRM (1981) [10]. Rock quality designation (RQD) values were obtained from the percentage of intact core pieces longer than 100 $\mathrm{mm}$ in the total length of core [9]. Rock discontinuity spacing values depend on the distance between each discontinuity. Meanwhile, discontinuity conditions were determined by the discontinuities surface and weathering condition. Groundwater conditions value was influenced by water inflow, water pressure, and its general condition. Discontinuity orientation values depend on strike and dip orientations, whether they are favorable or not for the structure planned in the study area. The RMR value range between 0 - 100 .

The tunnel support system has a basic function to keep the tunnel and its opening stable [11]. Tunnel support system can be classified as temporary and permanent. The rock mass classification and the tunnel support system in accordance with the RMR method obtain based on Bieniawski (1989) [9].

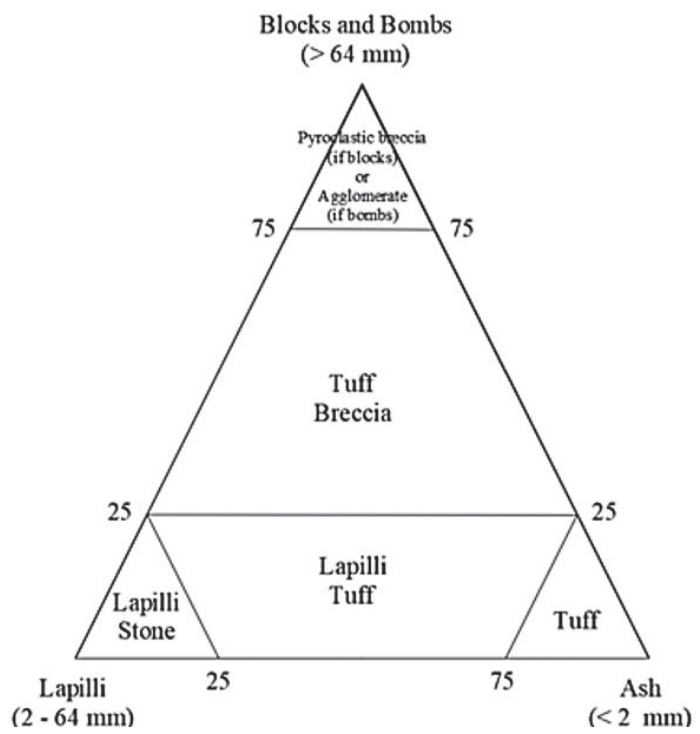

Fig. 3. Classification of pyroclastic rock [12].
The study area is a product of young volcanoes, thus the classification of pyroclastic rocks is based on Fisher's (1966) [12] classification as shown in Figure 2. The breccia rock that contains andesitic fragment classified by A. Streckeisen's (1976) [13] classification as shown in Figure 3. Geological structures were analyzed based on field observations and satellite imagery, while the degree of weathering of rock mass was determined based on ISRM (1981) [10].

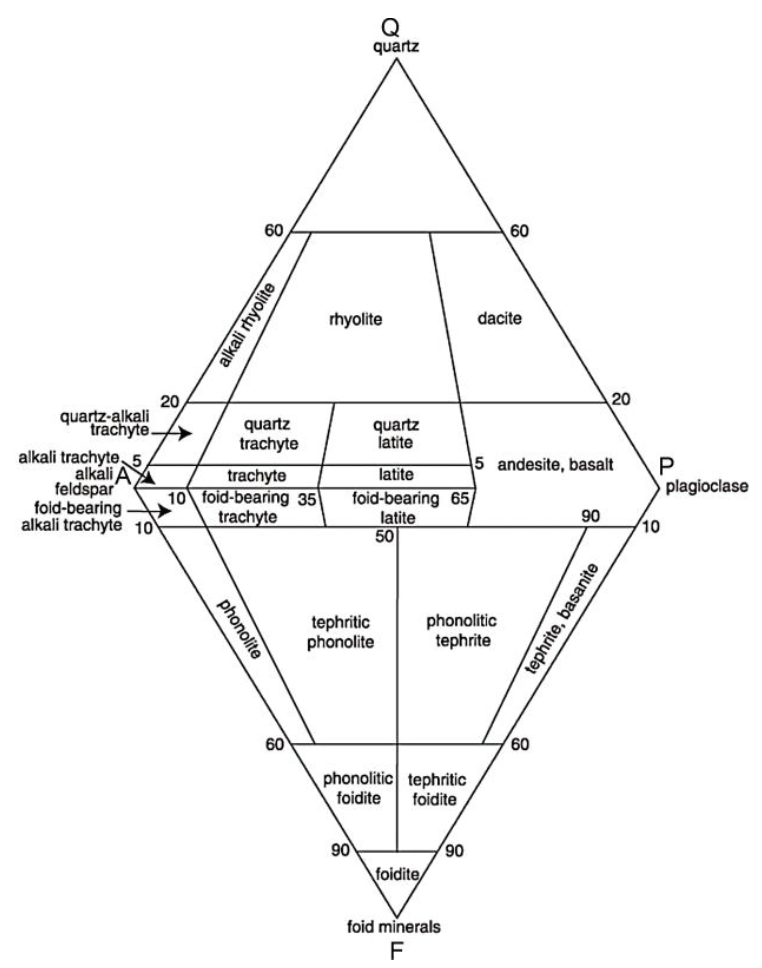

Fig. 4. Classification of plutonic rock [13].

\subsection{Determination of tunnel support systems based on Japan Society of Civil Engineers (2018)}

A safe tunnel support system based on the Japan Society of Civil Engineers [14] guidelines is carried out by determining the rock category/ class observed in the study area. Furthermore, it can be determined the types and specifications of the typical reinforcement required in the tunnel based on the rock category/ class.

\section{Results and discussions}

The study area is located in the hilly topography with a slope between 7 to 30 degrees. The lowest elevation is 649 meters, and the highest elevation is 760 meters above sea level in the study area. Meanwhile, the lowest ground-level elevation is $684 \mathrm{~m}$, and the highest is 744 $\mathrm{m}$ along the tunnel route. According to the bore log data, the subsurface conditions indicate that the rock layers have been moderate to highly weathered. The rock layers show only a few traces of the original rock, such as andesite and tuff. The rock layers from top to bottom 
are generally clay, silt, and sand. Based on bore log data, the groundwater table around Tunnel 10 is measured as $0.13 \mathrm{~m}-19.5 \mathrm{~m}$ beneath the surface, with water level variation considered as $2-3$ meters.

The presence of the Cimandiri fault and the Lembang fault affect the stability of the rock mass conditions in the study area. The two faults affect the formation of joints in the rock mass and affect the direction of rock mass movement if there is a shift in the fault. The Cimandiri fault is a left-lateral reverse fault located 2 kilometers southwest of the study area with six active segments, namely Loji, Cidadap, Nyalindung, Cibeber, Padalarang, and Saguling, with a total length of 100 kilometers. The Cimandiri fault has a $0.4-1 \mathrm{~mm} /$ year geodetic slip rate [2]. The Lembang Fault strikeslip fault with dominant sinistral motion movement of $1.95-3.45 \mathrm{~mm} /$ year. The Lembang fault is divided into six active segments, namely Cimeta, Cipogor, Cihideung, Gunung Batu, Cikapundung and Batu Lonceng with a total length of 29 kilometers [4].

The observations of surface rock in the study area show that there are 2 (two) rock units from old to young, namely andesitic breccia and tuff breccia. The units of andesitic breccia and tuff breccia have an interlocking relationship. The stratigraphic relationship between andesitic breccia, tuff breccia, and the subordinate units is unknown. Based on observations, the geological structure developed at the study area was faults and joints, while the rock outcrop in the study area did not have a layering area.

In the north-western part of the study area, there are 2 (two) faults, the first inferred fault is a normal fault with a northwest-southeast direction (Fig. 7) with an $\mathrm{N} 290^{\circ} \mathrm{E} / 70^{\circ}$ direction, and the second is the approximately located - inferred fault with a northeastsouthwest (ST 21 position in the study area shown in Figure 7) and an $\mathrm{N} 30^{\circ} \mathrm{E} / 80^{\circ}$ direction. The directions of dominant joint structures found in the study area are northeast (e.g., $\mathrm{N} 77^{\circ} \mathrm{E}-\mathrm{N} 80^{\circ} \mathrm{E}$ and $\mathrm{N} 63^{\circ} \mathrm{E}-\mathrm{N} 68^{\circ} \mathrm{E}$ ) and southwest (e.g., $\mathrm{N} 255^{\circ} \mathrm{E}-\mathrm{N} 250^{\circ} \mathrm{E}$ and $\mathrm{N} 285^{\circ} \mathrm{E}-$ $\mathrm{N} 288^{\circ} \mathrm{E}$ ). Analysis data from the measurement of the fractional orientation of the rocks in the study area implies that the main force that controls the fracture has a northeast-southwest direction.

The spread of tuff breccia rock reached $58.48 \%$ of the total study area (shown in Figure 7 as a dark brown area). The tuff breccia rock observed on the surface has a moderate to a highly level of weathering so that the rock structure is not visible. The color of the rock is dark brown, composed of fragments measuring $0.06-2 \mathrm{~mm}$ with a fine-sized matrix - a very fine, poorly sorted with open packaging. Rock mass in Figure 5 indicates that ST 4 (Fig. 7) has a disintegrated structure with poorly interlocked, heavily broken rock mass with a mixture of angular and rounded rock pieces. The surface condition in ST 4 is poor with a slickensided, highly weathered surface with compact coatings or fillings or angular fragments. The surface condition of the rock mass is poor quality with a high degree of weathering.

The spread of andesitic breccia reached $41.52 \%$ of the total study area (shown in Figure 7 as a light brown area). Andesitic breccia has moderate to highly level of surface rock weathering so that the rock structure is not visible. The dominant rock color is light brown, composed of andesitic fragments from granule to boulder size with a matrix of granule size to very fine, poor sorting with open packaging. Figure 6 below shows that rock mass at ST 5 (Fig. 7) has a moderately weathered matrix with mainly andesite fragment size from coarse to boulder.

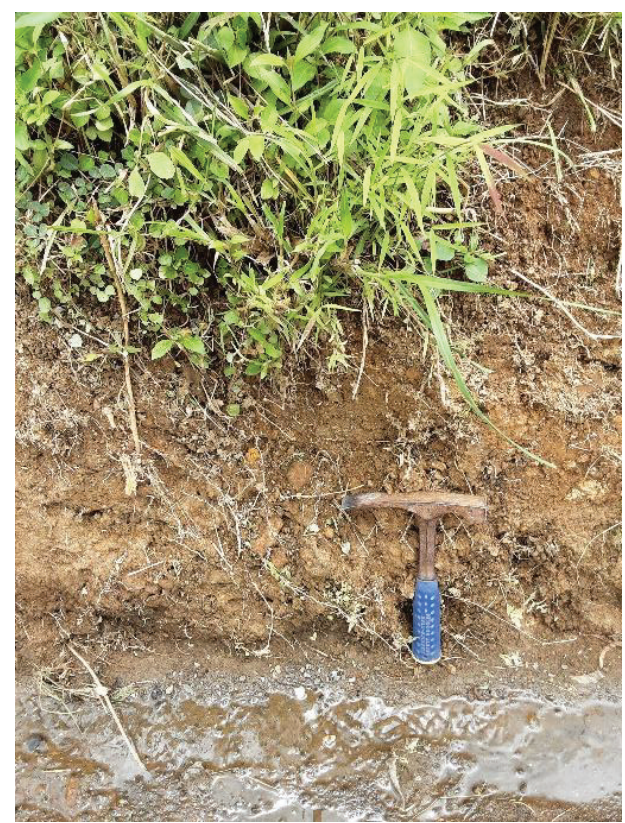

Fig. 5. Highly weathered tuff breccia in ST 4.

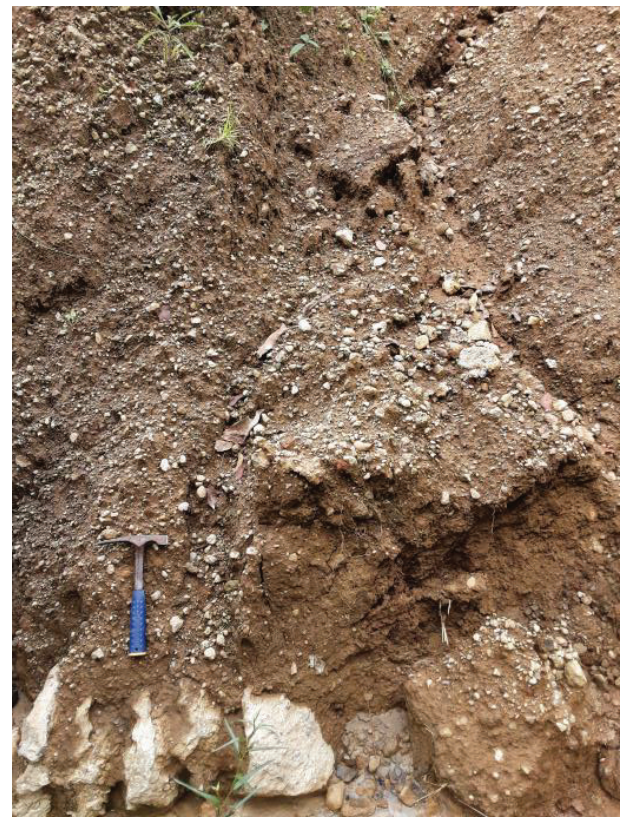

Fig. 6. Highly weathered andesitic breccia in ST 5 .

The division of lithology, cross sectional of geological map, and geological engineering map in the study area is shown in Figure 7, Figure 8, Figure 9, and Figure 10. 


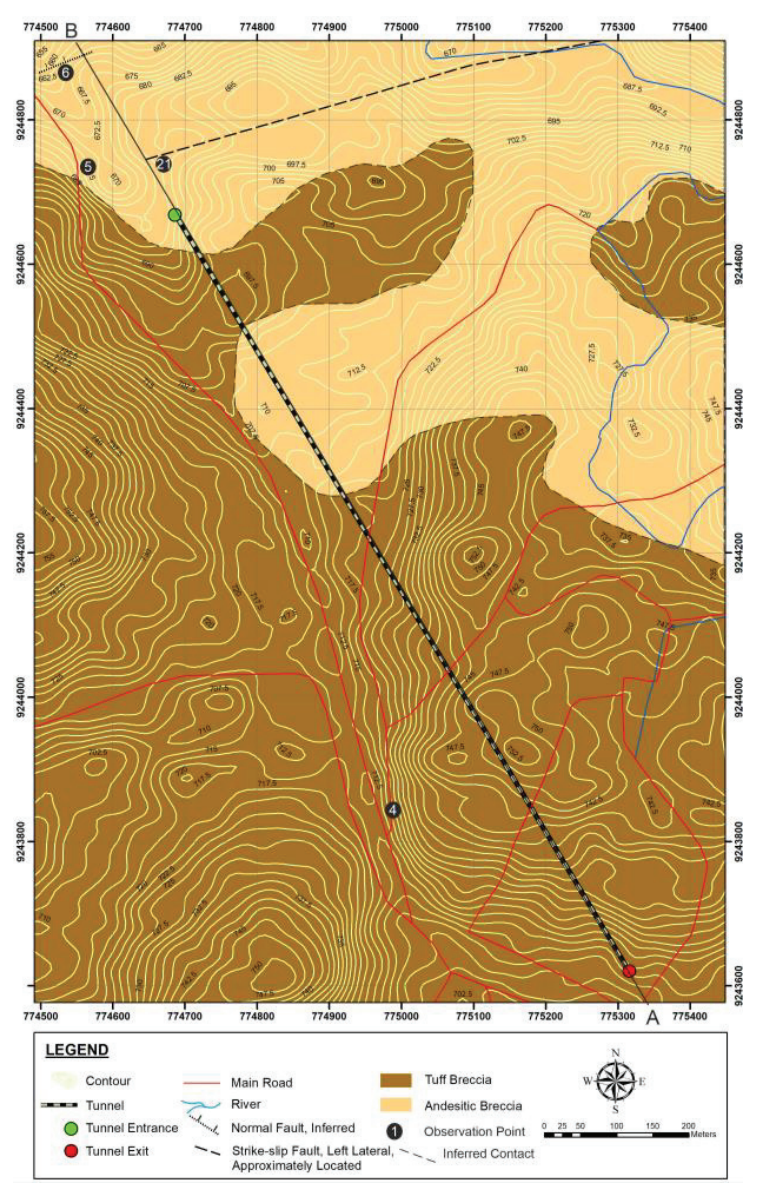

Fig. 7. Geological map of the study area.

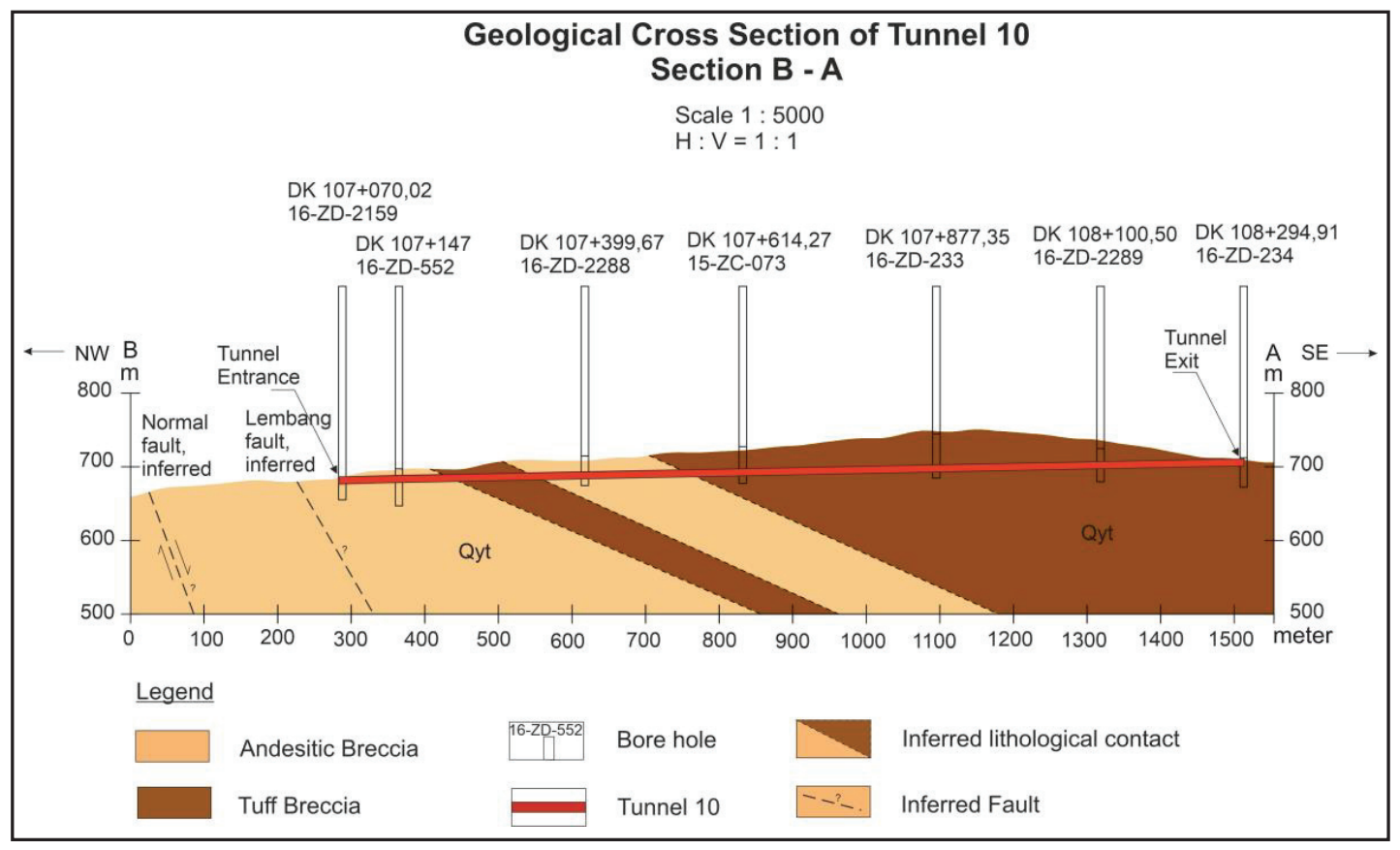

Fig. 8. Geological cross section of the study area. 


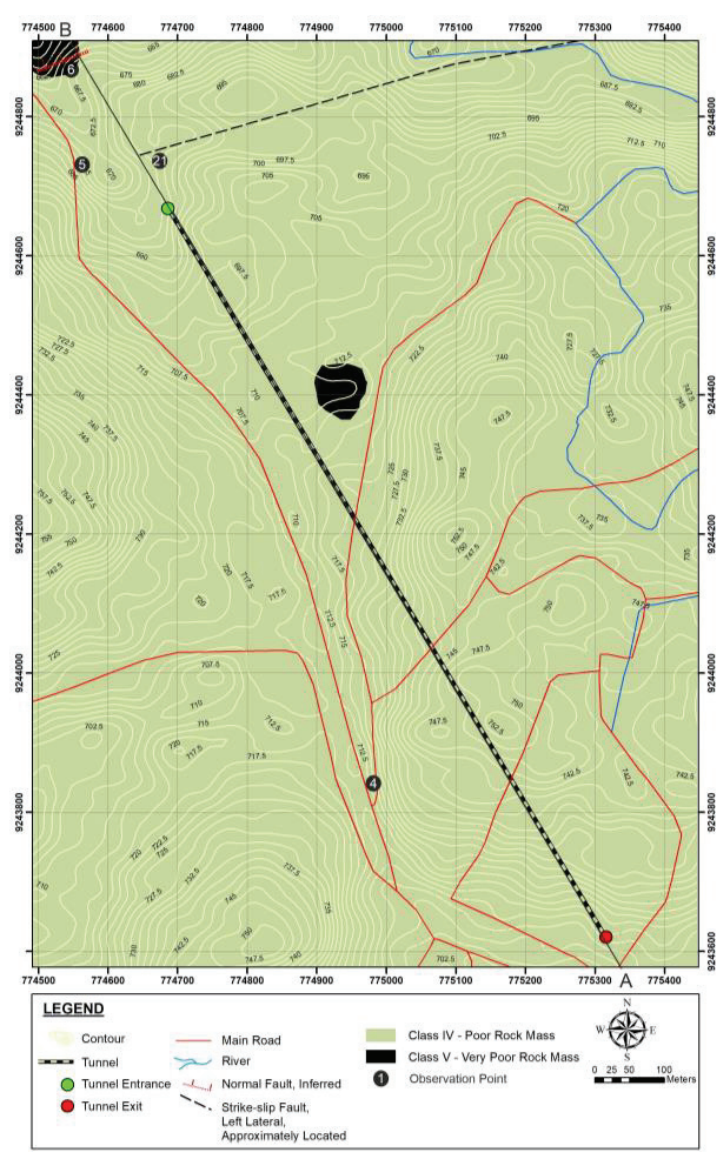

Fig. 9. Engineering geological map of the study area based on RMR.

The UCS value was determined in the field [10] as a rock mass quality parameter for the RMR method. The
UCS values obtained ranged from 1 - $25 \mathrm{MPa}$. Table 1 shows an example of determining the rock mass quality value using the RMR method.

Table 1. The rock mass quality value at ST 4 and ST 5 determined by the RMR method

\begin{tabular}{|l|c|c|}
\hline \multirow{2}{*}{\multicolumn{1}{c|}{ Parameters }} & ST 4 & ST 5 \\
\cline { 2 - 3 } & Rating & Rating \\
\hline UCS (MPa) & 1 & 4 \\
\hline RQD (\%) & 0 & 0 \\
\hline Spacing of Discontinuities & 5 & 10 \\
\hline Condition of Discontinuities & 20 & 20 \\
\hline Groundwater & 0 & 0 \\
\hline Strike and dip orientations & 0 & 0 \\
\hline RMR number & $\mathbf{2 6}$ & $\mathbf{3 4}$ \\
\hline
\end{tabular}

Based on the RMR calculation at ST 4 and ST 5, the total values of RMR are 26 and 34, respectively. This value indicates that the rock class belongs to class IV (RMR 21 - 40, poor rock). The rock mass in this category has a standing-up time of 10 hours for a $2.5 \mathrm{~m}$ span without support. According to Bieniawski (1989) [9], the support systems recommended for the tunnel in this rock mass category are rock bolts, shotcrete, and steel sets. The suitable excavation method is the top heading and bench with support installed while excavated.

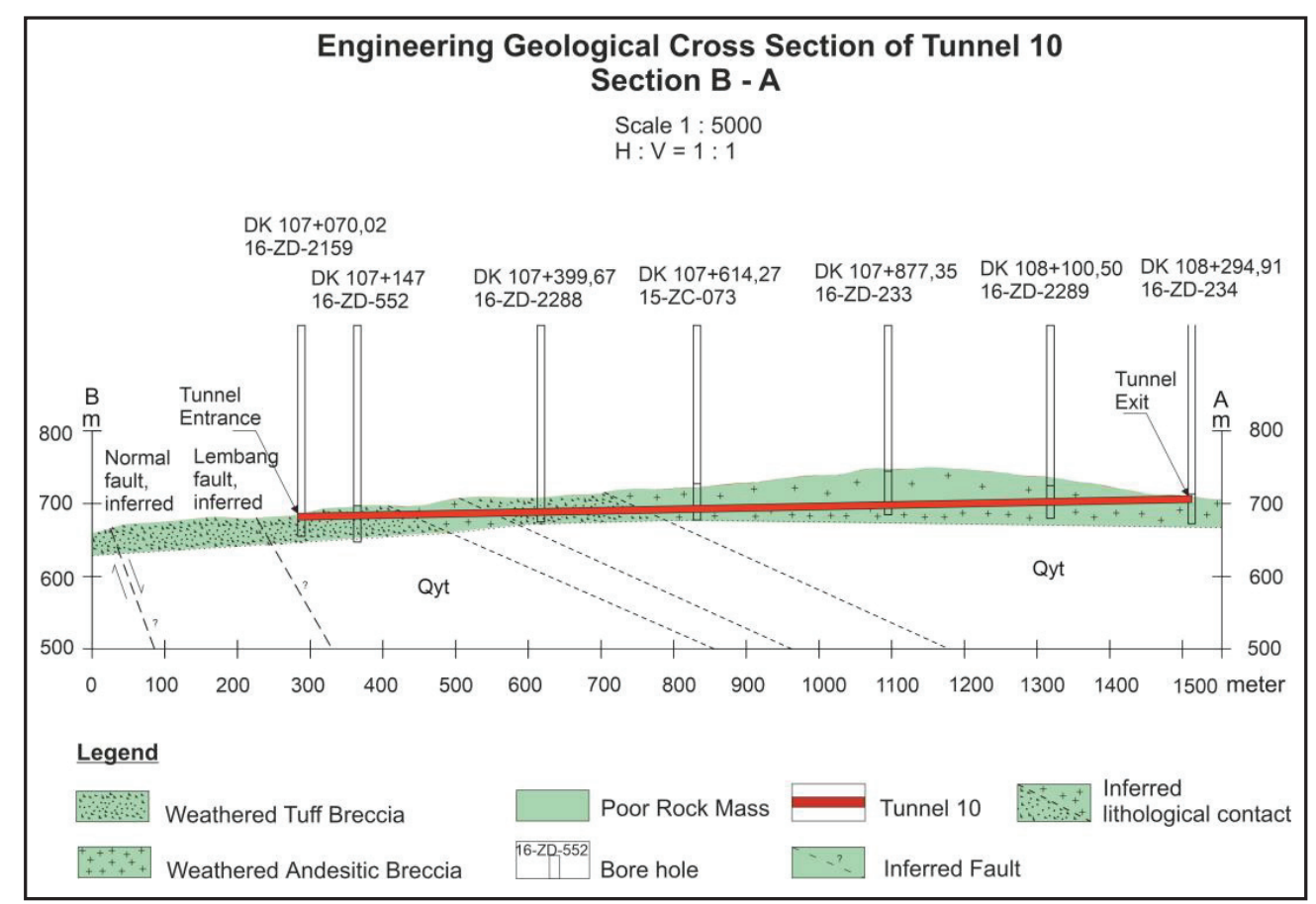

Fig. 10. Engineering geological cross section of the study area. 
Along with the RMR method, the tunnel support system in this study is determined according to the characterization of the surface rock mass using the JSCE (2018) method [14]. Determination of rock mass category for tunnel support system by the JSCE obtained from the engineering geological mapping results and the RMR results. The engineering geological mapping data shows that the study area consists of two mainly lithological units, namely tuff breccia $(58.48 \%$ of total study area) and andesitic breccia (41.52\% from total of area) with poor and weathered condition. Thus, the rock mass classification in the tunnel route is categorized as tuff breccia in the weak class that belongs to the DII category in the JSCE method, with the L Massive rock type. Rock mass in this category is weak rocks that can experience large plastic and elastic deformations. The strength of the rock is considered minor with the very poor conditions of discontinuity. Thus, the strength of the rock bonds due to tunneling is reduced along the discontinuities, which can easily slip and increase movement. The excavation surface is considered unstable, and reinforcement such as shotcrete is required at the face of the excavation plane. The descriptions of the DII category in the JSCE method suit the rock mass condition in the study area.

The double bench excavation method is recommended for the DII category rock to stabilize the excavation surface area easily. The reinforcement system suggested by the JSCE method for the DII category rocks is shotcrete, rock bolts, steel supports, and work floors (invert), provided that the concrete work floor is immediately placed or closure of the excavation cross-section. A typical schematic of the support patterns and allowable deformations in DII category rocks is shown in Table 2.

The lithological unit in this study was obtained from correlation of engineering geological mapping, bore log data, and laboratory test results of surface and subsurface samples. The data show that most rock mass in the study is moderate to highly weathered, without a layering area in the rock outcrops. The subsurface condition was interpreted from bore log data and correlated with the engineering geological mapping information.

The geological structures that control the study area, namely the Cimandiri fault and the Lembang fault, have a different direction of the dominant sense of movement. The existence of the geological structures interpreted from satellite imagery (DEM) and the Map of Earthquake Hazard of Indonesia, validated by engineering geological mapping in the suspected location. This condition shows that the study area has complex geological conditions with accumulated volcanic products mostly in weathered states. Because of this consideration, the RMR method was used to determine the rock mass quality that mainly focused on quantifying the discontinuity conditions in the study area.

The rock mass quality assessment from observation points based on the RMR method is mainly shown as Poor Rock Mass (Class IV) with a hint of Very Poor Rock Mass (Class V) in two minor locations (Fig. 9).
Thus, it can be concluded that the general rock mass condition in the study area is mainly in the poor category and highly weathered condition. Rock mass in this category has a small value of the UCS $(<25 \mathrm{MPa})$, cohesion $(<200 \mathrm{kPa})$, and friction angle $(<25$ degrees $)$. Poor rock quality can be easily deformed and destroyed by small energy, such as a knife or geological hammer.

Table 2. The excavation methods and tunnel support systems comparison in accordance with the RMR and JSCE methods.

\begin{tabular}{|c|c|c|}
\hline $\begin{array}{c}\text { Excavation } \\
\text { Method and } \\
\text { Tunnel Support } \\
\text { Systems } \\
\end{array}$ & The RMR method & The JSCE method \\
\hline 1. Excavation & $\begin{array}{l}\text { Top heading and } \\
\text { bench } 1.0-1.5 \mathrm{~m} \\
\text { advance in top } \\
\text { heading. } \\
\text { Install support } \\
\text { currently with } \\
\text { excavation, } 10 \mathrm{~m} \\
\text { from the face. }\end{array}$ & $\begin{array}{l}\text { Double bench } \\
\text { excavation } \\
\text { method }\end{array}$ \\
\hline \multicolumn{3}{|l|}{ 2. Supports } \\
\hline \multirow[t]{2}{*}{ - Rock bolts } & $\begin{array}{l}20 \mathrm{~mm} \text { diameter, } \\
\text { fully grouted }\end{array}$ & $6.0 \mathrm{~m}$ of length \\
\hline & $\begin{array}{l}\text { Systematic bolts } \\
4-5 \mathrm{~m} \text { long, } \\
\text { spaced } 1-1.5 \mathrm{~m} \text { in } \\
\text { crown and wall } \\
\text { with wire mesh }\end{array}$ & $\begin{array}{l}1.0 \mathrm{~m} \text { spacing of } \\
\text { circumferential } \\
\text { direction, } 1.0 \mathrm{~m} \text { or } \\
\text { less spacing of } \\
\text { longitudinal } \\
\text { direction in top } \\
\text { heading and } \\
\text { bench }\end{array}$ \\
\hline - Shotcrete & $\begin{array}{l}100-150 \mathrm{~mm} \text { in } \\
\text { crown and } 100 \\
\mathrm{~mm} \text { in sides }\end{array}$ & $\begin{array}{l}25 \mathrm{~cm} \text { in crown } \\
\text { and wall }\end{array}$ \\
\hline - Steel sets & $\begin{array}{l}\text { Light to medium } \\
\text { ribs spaced } 1.5 \mathrm{~m} \\
\text { where required. }\end{array}$ & $\begin{array}{l}\mathrm{H}-200 \text { beam in } \\
\text { top heading and } \\
\text { bench with } 1.0 \mathrm{~m} \\
\text { or less spacing }\end{array}$ \\
\hline - Lining & - & $\begin{array}{l}40 \mathrm{~cm} \text { arch in } \\
\text { sidewall and } 50 \\
\mathrm{~cm} \text { in invert }\end{array}$ \\
\hline $\begin{array}{l}\text { 3. Allowable } \\
\text { deformation }\end{array}$ & - & $10 \mathrm{~cm}$ \\
\hline
\end{tabular}

Rock mass condition based on the RMR classification and the JSCE category shows that the rock mass belongs to the poor category (Class IV and DII category). Figure 10 of the engineering geology crosssection of the study area shows that subsurface condition along the tunnel route is consists of weathered rock masses. This condition means that Tunnel 10 is located in a mainly poor rock mass with the possibility of numerous jointed rocks around the tunnel. The large plastic and elastic deformation can cause instability to tunnel excavation and structure. The rock mass already received generally strong weathering and alteration process with most of the materials turn into clay. Meanwhile, the soil materials mixed with pumice, tuff, and lapilli.

The comparison result between the RMR and the JSCE methods is shown in Table 2, including 
comparison of the excavation method and the tunnel support system.

According to Table 2, typical tunnel support systems based on the RMR recommendation are rock bolts with $20 \mathrm{~m}$ diameter and fully grouted, shotcrete with $100-$ $150 \mathrm{~mm}$ thickness in the crown and $100 \mathrm{~mm}$ thickness insides, and light to medium ribs spaced $1.5 \mathrm{~m}$ where required. Typical reinforcement schemes recommended for the tunnel according to JSCE (2018) are shotcrete with $25 \mathrm{~cm}$ thickness, steel support with $\mathrm{H}-200$ beam for top heading and bench support, arch sidewall with 40 $\mathrm{cm}$ thickness, and invert concrete with $25 \mathrm{~cm}$ thickness. Based on the results, the JSCE provides higher safety factor, shown in the specification of its support system that is higher than the RMR recommendation. Besides, the RMR method does not set the allowable deformation limit to the excavation plane and does not add lining as a support system. Meanwhile the JSCE method sets the allowable deformation limit as $10 \mathrm{~cm}$ and recommends lining with a $40 \mathrm{~cm}$ arch in the sidewall and $50 \mathrm{~cm}$ in the invert.

\section{Conclusion}

This paper describes the lithology unit, distribution, and rock mass quality in the study area and proposes a suitable support system for Tunnel 10 based on the geological condition. The lithology of the study area consists of andesitic breccia and tuff breccia with a distribution of $58.48 \%$ and $41.52 \%$ of the total study area, respectively. The rock mass has a moderate to a highly degree of weathering. The UCS values ranged from 1 - $25 \mathrm{MPa}$, and the RMR values ranged from 2140 , which indicated the rock mass categorized as class IV (poor rock). The JSCE categorized the rock mass in the study area as DII category, shown as a poor rock mass.

According to the results, this study prefers to use the JSCE recommendation as a tunnel support system for Tunnel 10 with shotcrete with $25 \mathrm{~cm}$ thickness, steel support with H-200 beam for top heading and bench support, arch side wall with $40 \mathrm{~cm}$ thickness, and invert concrete with $25 \mathrm{~cm}$ thickness. However, numerical methods need to be done to determine the most effective and efficient tunnel support system for Tunnel 10. Detailed engineering geological mapping and research of faults and discontinuities around the tunnel are needed to determine their effects on tunnel construction and other infrastructure.

The first author wishes to thank the Ministry of Public Works and Housing of the Republic of Indonesia for the opportunity and financial support to conduct this study. The authors would like to thank PT Kereta Cepat Indonesia - China (KCIC), High Speed Railway Contractor Consortium (HSRCC), China Railway Group Limited (CREC), and China Railway Design Corporation (CRDC) for the research permission and data support.

\section{References}

1. PT Kereta Cepat Indonesia - Cina (KCIC), Design Drawing of No. 10 Tunnel (2018)

2. G.I. Marliyani, J. R. Arrowsmith, K. X. Whipple, J. Geophys. Res. Earth Surf. E 121, 2287-2308 (2016)

3. Ministry of Public Works and Housing, Guidelines for Excavation Design Methods and Tunnel Reinforcement Systems in Mixed Soil-Rock Media (2015)

4. M.R. Daryono, D. H. Natawidjaja, B. Sapiie, P. Cummins, Tectonophysics. E 751, 180 - 191 (2018)

5. Sudjatmiko, Geologic Map of the Cianjur Quadrangle of Java (1972)

6. Bakosurtanal, West Java Province Map (2003)

7. G.I. Marliyani et al, Neotectonics of Java, Indonesia: Crustal Deformation in the Overriding Plate of an Orthogonal Subduction System (2016)

8. F. Hilmi, I. Haryanto, Bull. Sci. Contrib.: Geol. 6 (2008)

9. Z.T. Bieniawski, Engineering Rock Mass Classifications (John. Wiley \& Sons, New York, 1989)

10. ISRM, Rock Characterization Testing and Monitoring ISRM Suggested Method. E.T. Brown (Ed) (Pergamon Press, New York, 1981)

11. D.U. Deere, R. B. Peck, H. W. Parker, J. E. Monsees, B. Schmidt, Design of Tunnel Support Systems, (Whittles Publishing, 1970)

12. R.V. Fisher, Earth Sci. Rev. 1(4), 287-298 (1966)

13. A. Streckeisen, Earth Sci. Rev. 12(1), 1-33 (1976)

14. Japan Society of Civil Engineers (JSCE), Standard Specifications For Tunneling-2016: Mountain Tunnels (2018)

15. Ministry of Public Works and Housing, The Map of Indonesia Source and Earthquake Hazard (2017) 